\title{
Effects of glucagon-like peptide-1 and exendins on kinase activity, glucose transport and lipid metabolism in adipocytes from normal and type-2 diabetic rats
}

\author{
Verónica Sancho, María V Trigo, Nieves González, Isabel Valverde, Willy J Malaisse ${ }^{1}$ and \\ María L Villanueva-Peñacarrillo
}

Department of Metabolism, Nutrition and Hormones, Fundación Jiménez Díaz, Avda. Reyes Católicos, 2, 28040 Madrid, Spain

${ }^{1}$ Laboratory of Experimental Hormonology, Brussels Free University, Brussels, Belgium

(Requests for offprints should be addressed to M L Villanueva-Peñacarrillo; Email: mlvillanueva@ fjd.es)

\begin{abstract}
Several kinases have been implicated in the metabolic response of human and rat myocytes to glucagon-like peptide-1 (GLP-1), exendin-4 (Ex-4) and exendin-9 (Ex-9). We have investigated, in isolated rat adipocytes, the changes caused by GLP-1, Ex-4 and Ex-9 compared with those provoked by insulin or glucagon, upon the activity of phosphatidylinositol-3-kinase (PI3K), protein kinase B (PKB), p42/44 MAP kinases (MAPKs) and p70s6 kinase (p70s6k), and the participation of these kinases and protein kinase C (PKC) in their action upon 2-deoxy-D-glucose uptake, lipolysis and lipogenesis. The study was conducted in normal rats, and extended to a streptozotocin-induced type-2 diabetic model (STZ-rats). The participation of distinct kinases was estimated by using potential kinase inhibitors, including wortmannin, PD98059, rapamycin, H-7 and RO31-8220. In normal rat adipocytes, GLP-1 and both exendins share with insulin an increasing action upon the activity of all kinases studied (except PKB), PI3K, p44 and p42 MAPKs and possibly PKC, all being required for their stimulating effect upon glucose uptake. Ex-4 and Ex-9, like GLP-1 and insulin, have lipogenic action, while only Ex-4 shares with GLP-1 its lipolytic effect which is antagonized by Ex-9. MAP kinases and PKC seem to have an essential role in the GLP-1 and Ex-4 lipolytic action, as does PI3K in that of Ex-4. An increase in PI3K and MAPKs activity for the lipogenic effect of Ex-4, Ex-9 and GLP-1 are required, and in the case of Ex-4 and Ex-9, a stimulation of p70s6k activity is also needed. In cells from STZ-rats the magnitude of the above parameters was, in general, comparable to that in normal animals, with some exceptions: basal PI3K activity and lipogenesis were higher, GLP-1, Ex-4 and Ex-9 failed to modify basal lipogenesis but increased PKB activity, insulin failed to affect the activity of MAPKs and the insulin-induced glucose uptake was impaired. The impaired insulin effects upon some of the variables in the STZ-rat, distinct from those of GLP-1 and exendins, adds knowledge to the mechanism of the beneficial action of GLP-1 and Ex-4 in diabetic states.
\end{abstract}

Journal of Molecular Endocrinology (2005) 35, 27-38

\section{Introduction}

Glucagon-like peptide-1 (GLP-1), proposed as a therapeutic tool for type-2 diabetes, has insulinindependent antidiabetic properties (Gutniak et al. 1992, D'Alessio et al. 1995, Meneilly et al. 2001, Dardevet et al. 2004) which suggested that GLP-1 should have activity in extrapancreatic tissues participating in overall glucose homeostasis. In fact, it has been demonstrated in several studies that, in liver and muscle, GLP-1 not only has specific receptors (Delgado et al. 1995, Villanueva-Peñacarrillo et al. 1995), distinct (Valverde et al. 1994, Villanueva-Peñacarrillo et al. 1994, Yang et al. 1998) from those in the pancreas (Thorens 1992), but also that it exerts insulin-like stimulatory effects upon glucose transport and metabolism in normal (Valverde et al. 1994, Villanueva-Peñacarrillo et al. 1994, Luque et al. 2002) and diabetic (Morales et al. 1997,
López-Delgado et al. 1998) states; in addition, this incretin (Creutzfeldt 2001) modulates the glucose transporter levels in 3T3-L1 adipocytes (Wang et al. 1997) and in liver, fat tissue and skeletal muscle of normal and diabetic rats (Villanueva-Peñacarrillo et al. $2001 b)$.

In fat tissue, where the GLP-1 pancreatic receptor does not seem to be expressed (Bullock et al. 1996), the peptide also has specific binding sites (Mérida et al. 1993, Valverde et al. 1993), and is both lipogenic and lipolytic, apart from showing capability to stimulate parameters related to glucose metabolism (Ruiz-Grande et al. 1992, Perea et al. 1997, Wang et al. 1997, Miki et al. 1996, Villanueva-Peñacarrillo et al. 2001a).

Exendin(1-39)amide (Ex-4), a non mammalian peptide, shares $53 \%$ of its amino acid sequence with GLP-1; it is also insulinotropic (Cancelas et al. 2001a) and exerts GLP-1-like effects in rat liver and skeletal 
muscle, such as stimulation of glycogen synthase $\alpha$, glycogen synthesis and glucose oxidation and utilization (Alcántara et al. 1997). Its truncated form, exendin(9-39) amide (Ex-9), has been shown to be an antagonist of the GLP-1 receptor in various cell systems (Nielsen et al. 2004), and also of its effects in rat pancreas (Cancelas et al. 2001b), liver cells and muscle tissue (Alcántara et al. 1997). But in human myocytes, both exendins increase glucose transport (González et al. 2005) and metabolism (Luque et al. 2002), and have been shown to be agonists of the GLP-1 receptor in adipocyte (MontroseRafizadeh et al. 1997) and myocyte (Yang et al. 1998) cell lines.

GLP-1 increases phosphatidylinositol-3-kinase (PI3K) activity and phosphorylation of protein kinase $\mathrm{B}(\mathrm{PKB})$, $\mathrm{p} 44 / 42$ MAP kinases (p44/42 MAPKs) and p70s6 kinase (p70s6k) in human myocytes (González et al. 2005) and in rat hepatocytes (Redondo et al. 2003) and skeletal muscle (Acitores et al. 2004), as insulin does in rat hepatocytes (Redondo et al. 2003, Peak et al. 1998) and human myocytes (González et al. 2005). In human muscle cells, Ex-4 and Ex-9 both share with GLP-1 its stimulatory action on PI3K/PKB and p44/42 MAPK enzymes (González et al. 2005) although with an apparent lower potency.

Recent reports have drawn attention to the participation of several kinases in the metabolic response of both human and rat myocytes to GLP-1, Ex-4 and Ex-9 (González et al. 2005), and the perturbation of this coupling process in type-2 diabetes mellitus (Acitores et al. 2004, González et al. 2004). The aim of the present study was to investigate in normal rat adipocytes the effect of GLP-1, Ex4 and Ex-9, compared with that of insulin or glucagon, on the activity of PI3K, PKB, p70s6k and p42/p44 MAP kinases and the role of these enzymes in the action of GLP-1 and both exendins on 2-deoxy-D-glucose transport and lipid metabolism. As some metabolic responses to insulin are known to be impaired in diabetic states, together with the fact that GLP-1 and Ex-4 are currently under investigation as possible therapeutic tools, we extended the study to adipocytes from adult animals that had been injected with streptozotocin during the neonatal period (STZrats) - a current model of type-2 diabetes (Portha et al. 1979).

\section{Materials and methods}

\section{Reagents}

The following reagents were used: human GLP-1(7-36) amide (GLP-1; Bachem AG, Bubendorf, Switzerland); porcine insulin (Novo Biolabs, Bagsvaerd, Denmark); porcine glucagon (Lilly Co., Indianapolis, IN, USA); exendin(1-39)amide (Ex-4) and exendin(9-39)amide (Ex-9) (gifts from Dr John Eng, Veteran's Administration
Medical Center, NY, USA); PD98059 (PD) and RO31-8220 (RO) (Calbiochem, La Jolla, CA, USA); collagenase P (Roche Diagnostics GmbH, Mannheim, Germany); ethylenedinitrilotetraacetic acid (EDTA), bovine serum albumin (BSA), 1-(5-isoquinolinylsulfonyl)-2-methylpiperazine (H-7), rapamycin (RAP), wortmannin, cytochalasin B, glycerol, phosphatidylinositol and phosphatidylserine (Sigma Chemical Co., St Louis, MO, USA); streptozotocin (STZ) (Sigma-Aldrich Química S.A., Madrid, Spain); aprotinin (Trasylol, Bayer Leverkusen, Germany); 2-deoxy-D-[1,2${ }^{3} \mathrm{H}(\mathrm{N})$ ]glucose (2-DOG; Moravek Biochemicals, Brea, CA, USA); $\left[2-{ }^{14} \mathrm{C}\right]$ sodium acetate (Amersham Pharmacia Biotech, UK); dioctyl phthalate (Acros Organics, Fair Lawn, NJ, USA); Ultima Gold scintillation liquid (Packard, Gröninger, The Netherlands); adenosine triphosphate (ATP) and nicotinamide adenine dinucleotide (NAD) (Boehringer Mannheim, S.A., Barcelona, Spain); $\quad\left[\gamma^{32} \mathrm{P}\right]$ ATP $(30 \mathrm{Ci} / \mathrm{nmol})$, horseradish peroxidase-conjugated donkey anti-rabbit immunoglobulin, Rainbow markers, ECL-Western blotting kit, Hyperfilm ECL (Amersham Biosciencies, UK); rabbit anti-total and anti-phosphorylated form of p44/42 MAP kinases, p70s6k and PKB (Cell Signaling Technology, New England Biolabs, Beverly, MA, USA); and rabbit anti-PI3-kinase p85 (Upstate Biotechnology, Lake Placid, NY, USA). All other commonly used chemicals were from Sigma or Merck (Merck Pharma Quimica, S.A., Barcelona, Spain).

\section{Experimental animals}

Male Wistar rats, kept on a standard pellet diet (UAR, Panlab, Barcelona, Spain) and tap water which were both available ad libitum, were used. Rats were rendered diabetic by a single dose of streptozotocin (STZ, $100 \mu \mathrm{g} / \mathrm{g}$ body weight (bw)) dissolved in $25 \mu \mathrm{l} 0.05 \mathrm{M}$ $\mathrm{Na}$ citrate, $\mathrm{pH} 4 \cdot 5$, intraperitoneally administered on the day of birth (Portha et al. 1979); at the age of 6-7 weeks, those animals showing a glucose disappearance constant (K) below $2.5 \times 10^{-2} \mathrm{~min}^{-1}$ during an i.v. glucose tolerance test $(0.5 \mathrm{mg}$ glucose $/ \mathrm{g}$ bw, in $30 \mathrm{~s})$ were selected (Vicent et al. 1994). A total of 38 STZ-induced type-2 diabetic rats (STZ-rats) were used in this study. Their body weights and $\mathrm{K}$ values averaged $257 \pm 9 \mathrm{~g}$ and $1 \cdot 56 \pm 0 \cdot 11 \times 10^{-2} \min ^{-1}$ respectively.

\section{Cells}

Adipocytes were isolated at $37^{\circ} \mathrm{C}$, by enzymatic digestion with collagenase $\mathrm{P}$, from the rat epidydymal fat pads (Rodbell et al. 1964). Then, cells were resuspended in Krebs-Ringer Bicarbonate buffer supplemented with HEPES, Trasylol, BSA and without or with D-glucose, $\mathrm{pH} 7 \cdot 4$, at a density of $10^{6}$ cells $/ \mathrm{ml}$. 


\section{Kinase activity}

Cells $\left(10^{6}\right)$ were first incubated for $15 \mathrm{~min}$ in $1 \mathrm{ml} \mathrm{KRB}$ containing $30 \mathrm{mM}$ HEPES, $500 \mathrm{KIU} / \mathrm{ml}$ Trasylol, $1 \%$ BSA, and $3.3 \mathrm{mM}$ D-glucose, $\mathrm{pH} 7 \cdot 4$, followed by a 3 -min incubation in the absence or additional presence of GLP-1, Ex-4, Ex-9 or insulin. For the measurement of PI3K activity and that of phosphorylated PKB, p70s6k and p44/42 MAPKs, the cells were homogenized and maintained at $4{ }^{\circ} \mathrm{C}$ in $1.25 \%$ Triton containing $250 \mathrm{mM}$ sucrose, $20 \mathrm{mM}$ Tris/HCl, pH 7.6, $2.5 \mathrm{mM} \mathrm{MgCl}_{2}$, $50 \mathrm{mM}$ 2-mercaptoethanol, $1.2 \mathrm{mM}$ EGTA, $5 \mathrm{mM}$ $\mathrm{Na}_{4} \mathrm{P}_{2} \mathrm{O}_{7}, 50 \mathrm{mM} \mathrm{NaF}, 1 \mathrm{mM} \mathrm{Na} \mathrm{VO}_{4}, 30 \mathrm{U} / \mathrm{ml}$ bacitracin, $2 \mu \mathrm{M}$ leupeptin, $2 \mu \mathrm{M}$ pepstatin and $2 \mathrm{mM}$ PMSF. After centrifugation at $10000 \boldsymbol{g}$, the infranatant, containing cytosol and solubilized membranes, was kept at $-70{ }^{\circ} \mathrm{C}$ until assay. An aliquot volume was taken from all membrane preparation samples for protein content determination (Bradford 1976).

PI3K activity was estimated as Phosphatidyl Inositol Phosphate $\left(\mathrm{PIP}_{2}\right)$ phosphorylation to $\mathrm{PIP}_{3}$, in p85 immunoprecipitates obtained by treating each adipocyte membrane preparation with anti-PI3-kinase p85 and subsequent coupling to protein A-agarose. The immunoprecipitates were incubated for $20 \mathrm{~min}$ at room temperature with $20 \mu \mathrm{M}\left[\gamma^{32} \mathrm{ATP}\right](5 \mu \mathrm{Ci} / \mathrm{nmol})$ in $6.25 \mathrm{mM}$ HEPES, $5 \mathrm{mM} \mathrm{MgCl}_{2}$ and $0.25 \mathrm{mM}$ EGTA, and in the presence of $0.25 \mathrm{mg} / \mathrm{ml}$ phosphatidylinositol/ phosphatidylserine as substrate; the reaction was interrupted by addition of $400 \mu \mathrm{l}$ chloroform/methanol/ $\mathrm{HCl}(1: 2: 1, \mathrm{v} / \mathrm{v}), 150 \mu \mathrm{l}$ chloroform and $150 \mu \mathrm{l} \mathrm{HCl}$. After centrifugation $(10000 \boldsymbol{g})$, the organic phase was treated with an equal volume of methanol/100 mM $\mathrm{HCl} / 2.5 \mathrm{mM}$ EDTA $(1: 1: 1, \mathrm{v} / \mathrm{v})$, and the new organic phase was separated by centrifugation and then speed-vac dried. The lipidic extract, redissolved in chloroform, was spotted, together with $\mathrm{PIP}_{3}$ standard, on a silicagel TLC plate, and developed in $n$-propanol/ acetic acid $/ \mathrm{H}_{2} \mathrm{O}$ (66:2:33, v/v). Plates were dried, and radioactive $\mathrm{PIP}_{3}$ was subsequently visualized by autoradiography and analyzed by densitometric scanning. In all experiments, the densitometric measurement of the band corresponding to cells incubated in the absence of peptide, was used as the control value (Redondo et al. 2003).

For the measurements of the degree of phosphorylation of the respective protein kinases by immunoblotting, equal amounts of each solubilized membrane preparation sample were subjected to SDS-PAGE (Laemmli 1970) on an 8\% resolving gel, in parallel with molecular weight markers; the separated proteins were then transferred to a nitrocellulose membrane, in a semidry system (Trans-blot SD semidry transfer cell, BioRad). For immunodetection, a Western blotting kit was used following the manufacturer's instructions, using total and phosphorylated antibody for each protein kinase, and a horseradish peroxidase-conjugated donkey anti-rabbit immunoglobulin second antibody; detection was by the enhanced chemiluminescence method, and quantitation was by densitometric scanning of the autoradiography (Redondo et al. 2003). The densitometric measurement of the phosphorylated protein kinase was normalized with respect to that of the total (percent of phosphorylated/total kinase), and the value obtained in adipocytes incubated in the absence of peptide was used as the control value.

\section{Glucose transport}

Cells $\left(10^{5}\right)$ were incubated for $15 \mathrm{~min}$ at $37^{\circ} \mathrm{C}$ in $400 \mu \mathrm{l}$ KRB, $10.9 \mathrm{mM}$ HEPES, $500 \mathrm{KIU} / \mathrm{ml}$ Trasylol and $2 \%$ BSA, pH 7•4, and either without (basal) or with GLP-1, Ex-4, Ex-9 or insulin alone or combined with $10^{-6} \mathrm{M}$ wortmannin (a PI3K inhibitor), $2.5 \times 10^{-5} \mathrm{M}$ PD (a p44/42 MAPKs inhibitor), $10^{-7} \mathrm{M}$ RAP (a p70s6k inhibitor), $10^{-4} \mathrm{M} \mathrm{H}-7$ or $10^{-7} \mathrm{M} \mathrm{RO}$ (PKC inhibitors). This was followed by a 3 -min incubation in the additional presence of $0.2 \mu \mathrm{Ci}(6.5 \mathrm{pmol}) 2$-deoxy-D-[1,2${ }^{3} \mathrm{H}(\mathrm{N})$ ] glucose (final concentration $16.3 \mathrm{nM}$ 2-DOG). Adipocytes, after being separated at $10900 \boldsymbol{g}$ in $100 \mu \mathrm{l}$ dioctyl phthalate, were added to $3 \mathrm{ml}$ scintillation liquid for $\beta$-counting. The total D-glucose content was corrected for the unspecific D-glucose uptake value, obtained in cell samples from each experiment treated in parallel with 0.175 mM cytochalasin B (Perea et al. 1997).

\section{Lipolysis}

Lipolysis was determined as glycerol release, following Wieland's enzymatic procedure (Wieland 1963), with some modifications (Perea et al. 1995). In brief, isolated adipocytes $\left(10^{5}\right.$ cells $)$ were incubated for $60 \mathrm{~min}$ at $37^{\circ} \mathrm{C}$, in $300 \mu \mathrm{KRB}$ supplemented with $10.9 \mathrm{mM}$ HEPES, $500 \mathrm{KIU} / \mathrm{ml}$ Trasylol, $3.3 \mathrm{mM}$ D-glucose and 3\% BSA, and in the absence (basal) or presence of GLP-1, Ex-4, Ex-9 or glucagon alone or in combination, and without and with $10^{-6} \mathrm{M}$ wortmannin (a PI3K inhibitor), $2.5 \times 10^{-5} \mathrm{M}$ PD (a p44/42 MAPKs inhibitor), $10^{-7} \mathrm{M}$ RAP (a p70s6k inhibitor), $10^{-4} \mathrm{M} \mathrm{H}-7$ or $10^{-7} \mathrm{M} \mathrm{RO}$ (PKC inhibitors); then, 0.45 $\mathrm{M} \mathrm{HClO}_{4}$ was added to the media, and the mixture was maintained for $10 \mathrm{~min}$ at $4^{\circ} \mathrm{C}$ and centrifuged at $2000 \mathrm{~g}$; the supranatant was $\mathrm{pH}$ neutralized with $20 \% \mathrm{KCO}_{3} \mathrm{H}$, separated at $3000 \boldsymbol{g}$, and its glycerol content was spectrophotometrically measured as NADH produced in the presence of ATP, NAD and the appropriate enzymes, from the absorption at $340 \mathrm{~nm}$; known amounts of glycerol were used as standards of reference.

\section{Lipogenesis}

Lipogenesis was judged from the incorporation of $\left[2-{ }^{14} \mathrm{C}\right] \mathrm{Na}$ acetate, as precursor, into lipids. Adipocytes 
Table 1 Effect of insulin, GLP-1, Ex-4 and Ex-9 on basal kinase activity in adipocytes from normal and STZ-rats. Results are means \pm S.E.M.

\begin{tabular}{|c|c|c|c|c|c|}
\hline & P13K & PKB & p70s6k & p42 MAPK & p44 MAPK \\
\hline \multicolumn{6}{|l|}{ Normal rats } \\
\hline Basal & $100(5)$ & $100(6)$ & $100(7)$ & $100(9)$ & $100(9)$ \\
\hline Insulin $\left(10^{-9} \mathrm{M}\right)$ & $129 \pm 4(10)^{*}$ & $244 \pm 21(10)^{*}$ & $150 \pm 11(10)^{*}$ & $173 \pm 14(15)^{*}$ & $181 \pm 29(15)^{*}$ \\
\hline GLP-1 $\left(10^{-12} \mathrm{M}\right)$ & $105 \pm 7(10)$ & $73 \pm 6(9)$ & $146 \pm 13(8)^{*}$ & $148 \pm 9(14)^{\star}$ & $164 \pm 13(14)^{*}$ \\
\hline GLP-1 $\left(10^{-9} \mathrm{M}\right)$ & $143 \pm 7(6)^{*}$ & $75 \pm 7(8)$ & $153 \pm 11(9)^{\star}$ & $145 \pm 12(14)^{*}$ & $162 \pm 15(13)^{*}$ \\
\hline Ex-4 (10-9 M) & $141 \pm 4(6)^{\star}$ & $72 \pm 12(5)$ & $171 \pm 38(3)^{*}$ & $142 \pm 16(8)^{\star}$ & $162 \pm 27(9)^{*}$ \\
\hline Ex-9 (10-9 M) & $146 \pm 8(6)^{*}$ & $76 \pm 12(5)$ & $155 \pm 27(3)^{*}$ & $143 \pm 11(9)^{*}$ & $183 \pm 20(8)^{*}$ \\
\hline \multicolumn{6}{|l|}{ STZ rats } \\
\hline Basal & $100(4)$ & $100(6)$ & 100 (3) & $100(6)$ & $100(6)$ \\
\hline Insulin $\left(10^{-9} \mathrm{M}\right)$ & $137 \pm 5(4)^{*}$ & $284 \pm 15(10)^{*}$ & $199 \pm 45(3)^{*}$ & $77 \pm 6(7)$ & $90 \pm 9(11)$ \\
\hline GLP-1 $\left(10^{-12} \mathrm{M}\right)$ & $149 \pm 17(3)^{*}$ & $97 \pm 7(10)$ & $89 \pm 1(3)$ & $88 \pm 6(8)$ & $97 \pm 10(8)$ \\
\hline GLP-1 $\left(10^{-9} \mathrm{M}\right)$ & $135 \pm 14(4)^{*}$ & $173 \pm 15(10)^{*}$ & $163 \pm 16(3)^{*}$ & $138 \pm 6(10)^{*}$ & $154 \pm 11(10)^{*}$ \\
\hline Ex-4 $\left(10^{-12} \mathrm{M}\right)$ & $141 \pm 19(3)^{*}$ & $97 \pm 10(5)$ & - & $154 \pm 6(4)^{\star}$ & $92 \pm 8(5)$ \\
\hline Ex-4 $\left(10^{-9} M\right)$ & $142 \pm 11(3)^{*}$ & $167 \pm 24(3)^{*}$ & $109 \pm 12(4)$ & $164 \pm 32(5)^{*}$ & $148 \pm 17(3)^{*}$ \\
\hline Ex-9 $\left(10^{-12} M\right)$ & $91 \pm 14(3)$ & - & - & $120 \pm 5(4)$ & $150 \pm 7(4)^{\star}$ \\
\hline Ex-9 $\left(10^{-9} M\right)$ & $132 \pm 3(3)^{\star}$ & $173 \pm 31(5)^{*}$ & $149 \pm 8(3)^{*}$ & $137 \pm 14(3)^{*}$ & $166 \pm 15(3)^{*}$ \\
\hline
\end{tabular}

${ }^{*} P<0.05$ vs basal value.

$\left(10^{5}\right.$ cells) were incubated at $37^{\circ} \mathrm{C}$ for $15 \mathrm{~min}$ in $400 \mu \mathrm{l}$ KRB, $10 \cdot 9 \mathrm{mM}$ HEPES, $500 \mathrm{KIU} / \mathrm{ml}$ Trasylol, $3 \cdot 3 \mathrm{mM}$ D-glucose and $3 \% \mathrm{BSA}, \mathrm{pH} 7 \cdot 4$, and without (basal) or with GLP-1, Ex-4, Ex-9 or insulin alone or combined with $\quad 10^{-6} \mathrm{M} \quad$ wortmannin (PI3K inhibitor), $2.5 \times 10^{-5} \mathrm{M}$ PD (p44/42 MAPKs inhibitor) $10^{-7} \mathrm{M}$ RAP (p70s6k inhibitor), $10^{-4} \mathrm{M} \mathrm{H}-7$ or $10^{-7} \mathrm{M} \mathrm{RO}$ (PKC inhibitors). This was followed by a 60-min incubation at $37^{\circ} \mathrm{C}$ in the additional presence of $0 \cdot 4 \mathrm{mM} \quad\left[2-{ }^{14} \mathrm{C}\right] \mathrm{Na}$ acetate $(0 \cdot 156 \mu \mathrm{Ci} / \mu \mathrm{mol})$. Adipocytes, after being separated at $10900 \boldsymbol{g}$ in $100 \mu \mathrm{l}$ dioctyl phthalate, were added to $3 \mathrm{ml}$ scintillation liquid for $\beta$-counting; the blank value was measured in vials containing all reagents but no cells and subjected in parallel to the same procedure.

\section{Statistical study}

All data are presented as mean values ( \pm S.E.M.) together with either the number of individual determinations $(n)$ or degrees of freedom (d.f.). The statistical significance of differences were determined using either analysis of variance or the Student's $t$-test.

\section{Results}

\section{Effect on kinases activation}

In adipocytes from normal rats, the response of the kinases (other than PI3K) to $10^{-12} \mathrm{M}$ and $10^{-9} \mathrm{M}$ GLP-1 was not significantly different; with PI3K, on the other hand, while there was no effect of GLP-1 at the $10^{-12} \mathrm{M}$ dose, there was a higher and significant $(P<0 \cdot 005)$ increase at $10^{-9} \mathrm{M}$ GLP-1 (Table 1). At
$10^{-9} \mathrm{M}$, the effect of GLP-1 was not different from that found with either Ex-4 or Ex-9. Pooling together the results obtained with GLP-1 and exendins, the stimulation of enzyme phosphorylation was not different from that found with $10^{-9} \mathrm{M}$ insulin in the case of $\mathrm{p} 44$ MAPK and p70s6k, it was higher $(P<0.02)$ in the case of PI3K, and lower $(P<0.05)$ in that of p42 MAPK. Moreover, whilst insulin highly increased $\mathrm{PKB}$ activity $(P<0.001)$, GLP-1, Ex-4 and Ex-9 inhibited $(P<0.001)$ such a phosphorylation to $74 \pm 5 \%(n=18)$ of basal value.

In adipocytes from STZ-rats, the basal activity of the kinases was not significantly different $(P>0 \cdot 3)$ from that found in normal rats, except in the case of PI3K, which averaged $195 \pm 9 \%(n=4 ; P<0 \cdot 005)$ of that in normal animals. Also, adipocytes from the diabetic rats (Table 1 ) differed in several other respects. First, whilst insulin $\left(10^{-9} \mathrm{M}\right)$ enhanced PI3K $(P<0 \cdot 01)$, PKB $(P<0 \cdot 001)$ and p70s6k $(P<0 \cdot 06)$ activity as in the normal animals, it failed to affect $(P>0.7)$ the phosphorylation of $\mathrm{p} 44$ MAPK, and decreased $(P<0 \cdot 01)$ that of 442 MAPK. For $\mathrm{PI} 3 \mathrm{~K}, \mathrm{PKB}$ and $\mathrm{p} 70 \mathrm{~s} 6 \mathrm{~K}$, the mean readings recorded in the presence of insulin, relative to the paired basal value, were higher, averaging $116 \cdot 9 \pm 6 \cdot 1 \%(n=17 ; P<0 \cdot 02)$ of the mean corresponding value found in normal animals $(100 \cdot 0 \pm 3 \cdot 8 \% ; n=30)$. Secondly, GLP-1, when tested at $10^{-9} \mathrm{M}$, increased $(P<0 \cdot 001)$ PKB phosphorylation, as opposed to the inhibition found in normal rats, while no difference of its effect upon the four other kinases was detected. However, when the concentration of GLP-1 was decreased to $10^{-12} \mathrm{M}$, a trend towards an inhibition of PKB, p70s6k, p42 MAPK and p44 MAPK phosphorylation was observed in the STZ-rats, the values averaging $93.7 \pm 3.9 \% \quad(n=29 ; \quad P>0 \cdot 1)$. This 
contrasted with the fact that as little as $10^{-12} \mathrm{M}$ GLP-1 was sufficient to augment $(P<0 \cdot 05)$ the basal PI3K activity. Lastly, in the case of both Ex-4 and Ex-9 $\left(10^{-9} \mathrm{M}\right)$, an increased phosphorylation $(P<0 \cdot 01)$ of $\mathrm{PKB}$ was again observed in the STZ-rats, whilst the effects on the other four kinases were not significantly different from those in normal animals (Table 1).

\section{Uptake of 2-deoxy-D-[1,2-33 $\mathrm{H}]$ glucose}

In normal rats, the basal value for D-glucose net uptake averaged $27 \cdot 2 \pm 0 \cdot 8 \mathrm{fmol} / 10^{5}$ cells $(n=476)$. Relative to the mean basal value recorded within the same experiment(s), the readings in the presence of GLP-1, Ex-4 and Ex-9 (all $10^{-9} \mathrm{M}$ ) averaged, respectively, $148 \cdot 5 \pm 3 \cdot 8 \% \quad(n=165), \quad 144 \cdot 1 \pm 3 \cdot 5 \% \quad(n=129) \quad$ and $147 \cdot 8 \pm 4 \cdot 0 \%(n=186)$; although these values were not significantly different from one another, the overall mean value $(147 \cdot 0 \pm 2 \cdot 2 \% ; n=480)$ was slightly, but significantly $(P<0.025)$ lower than that recorded in the case of insulin $(157 \cdot 4 \pm 4 \cdot 1 \% ; n=151)$. Likewise, when comparing the readings recorded within the same experiment(s), those obtained in the presence of GLP-1 $(160 \pm 9 \% ; n=46), \mathrm{Ex}-4(167 \pm 13 \% ; n=16)$ and $\mathrm{Ex}-9$ $(156 \pm 9 \% ; n=57)$ yielded an overall mean percentage of $159 \pm 6 \%(n=119)$, as distinct $(P<0 \cdot 02)$ from $191 \pm 12 \%$ $(n=34)$ in the presence of insulin. The concentrationresponse relationships (Fig. 1) for the effect of insulin, GLP-1, Ex-4 and Ex-9 were essentially comparable; thus, the threshold value was close to $10^{-12}$ to $10^{-11} \mathrm{M}$, and a maximal response was reached at $10^{-9}$ to $10^{-8} \mathrm{M}$.

The basal D-glucose uptake was decreased $(P<0 \cdot 005)$ by PD and H-7 to $89 \cdot 6 \pm 3 \cdot 2 \%(n=69)$ and $87 \cdot 8 \pm 2 \cdot 1 \%$ $(n=70)$ respectively, while in the presence of wortmannin $(93 \cdot 4 \pm 3 \cdot 7 \% ; n=93), \operatorname{RAP}(103 \cdot 4 \pm 2 \cdot 3 \% ; n=98)$ and RO $(105 \cdot 4 \pm 1 \cdot 8 \% ; n=47)$, no significant differences compared with the corresponding basal values were found.

As shown in Fig. 2, wortmannin, $\mathrm{PD}$ and $\mathrm{H}-7$ abolished, as a rule, the response to insulin, GLP-1, Ex-4 and Ex-9 $\left(10^{-9} \mathrm{M}\right.$ in all cases), the measurements made in the presence of both the agonist and the potential inhibitor being not significantly different from those in the presence of the inhibitor alone. The sole exception was in the case of wortmannin and Ex-4, when the value, although lower $(P<0 \cdot 001)$ than that recorded in the presence of Ex-4 alone, remained somewhat higher $(P<0.001)$ than that found in the presence of wortmannin alone. The two other potential inhibitors (RAP and RO) failed to affect significantly the response to insulin, GLP-1, Ex-4 or Ex-9.

In streptozotocin-induced type-2 diabetic rats, three differences became obvious: (1) basal glucose uptake $\left(45 \cdot 0 \pm 2 \cdot 7 \mathrm{fmol} / 10^{5}\right.$ cells; $\left.n=86\right)$ was higher $(P<0 \cdot 001)$ than that in normal animals; (2) the threshold
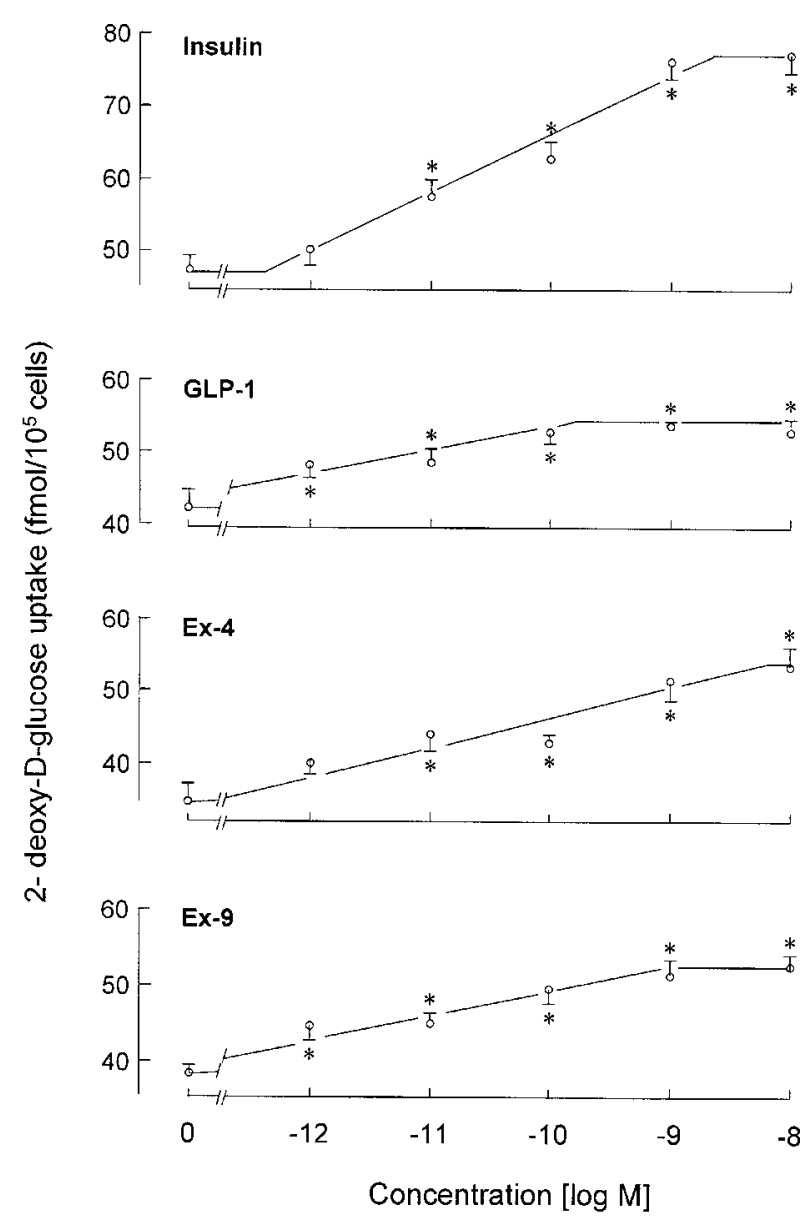

Figure 1 Effects of increasing concentrations of insulin, GLP-1, Ex-4 and Ex-9 on 2-deoxy-D-glucose uptake in normal rat adipocytes. Mean values are expressed relative to the mean basal value found within the same experiment(s), and refer to 11 to 26 separate determinations. ${ }^{*} P<0.05$ compared with the basal value.

stimulation by insulin, but not by GLP-1, Ex-4 and Ex-9, was also higher $\left(10^{-10} \mathrm{M}\right)$ than in normal rats $\left(10^{-11} \mathrm{M}\right)$, and $(3)$ at high concentrations $\left(10^{-9}\right.$ to $\left.10^{-8} \mathrm{M}\right)$, yielding a close-to-maximal stimulation of glucose uptake, the response to insulin represented only $80 \cdot 0 \pm 3 \cdot 1 \%(P<0 \cdot 001$; d.f. $=80)$ of that found in normal rats. Once again, such a decreased responsiveness to insulin was not reproduced with GLP-1, Ex-4 or Ex-9 $\left(10^{-9}\right.$ to $\left.10^{-8} \mathrm{M}\right)$, where the results averaged $96 \cdot 6 \pm 2 \cdot 3 \%(P>0 \cdot 1 ;$ d.f. $=206)$ of the mean readings recorded in normal animals, a value higher $(P<0 \cdot 001)$ than that found with insulin.

\section{Lipolysis}

In normal rats, the basal value for lipolysis averaged $19 \cdot 2 \pm 0 \cdot 6 \mathrm{nmol}$ glycerol $/ 10^{5}$ cells $(n=194)$. Both GLP- 1 


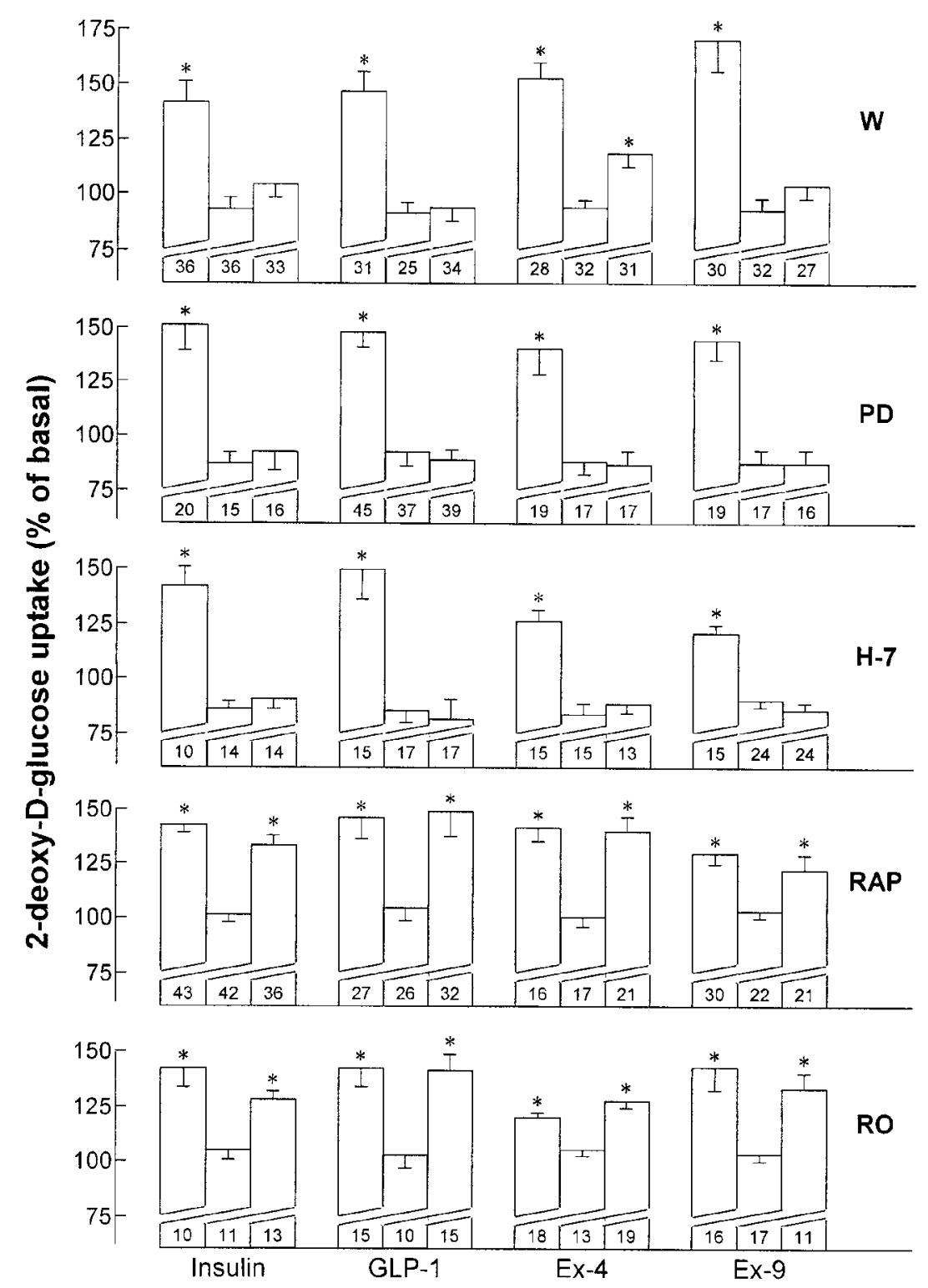

Figure 2 Effects of wortmannin (W), PD, H-7, RAP and RO on 2-deoxy-D-glucose uptake stimulated by insulin, GLP-1, Ex-4 or Ex-9 in normal rat adipocytes. Each group of bars refers to the results found within the same experiment(s) in the presence of the agonist alone (left hand bar), in the presence of the potential inhibitor alone (middle bar) and to the concomitant presence of the agonist and inhibitor (right hand bar). Mean values are expressed relative to the mean basal value found within the same experiment(s), and are derived from the number of separate measurements indicated at the bottom of each bar. ${ }^{*} P<0.05$ compared with the basal value.

and Ex-4 exerted a stimulatory effect (Fig. 3), with respective threshold concentrations close to $10^{-12} \mathrm{M}$ and $10^{-11} \mathrm{M}$. The highest mean values recorded at $10^{-9} \mathrm{M} \quad$ GLP-1 $(193 \pm 9 \% ; n=33)$ and $\mathrm{Ex}-4$ $(189 \pm 12 \% ; n=22)$ were not different from one another. When examined within the same experiment(s), the response to $10^{-9} \mathrm{M}$ GLP-1 did not differ (d.f.=20;
$P>0 \cdot 8)$ from the response to $10^{-9} \mathrm{M}$ glucagon. At $10^{-11} \mathrm{M}$, Ex-4 stimulated lipolysis $(P<0 \cdot 001)$ and increased the response to GLP- $1\left(10^{-13}, 10^{-12}\right.$ and $10^{-11} \mathrm{M}$ ), the readings recorded in the presence of both agents averaging $113 \cdot 3 \pm 1.9 \%(n=33 ; P<0 \cdot 001)$ of the corresponding mean values recorded in the presence of GLP-1 alone $(100 \cdot 0 \pm 1 \cdot 5 \% ; n=22)$; this resulted, 


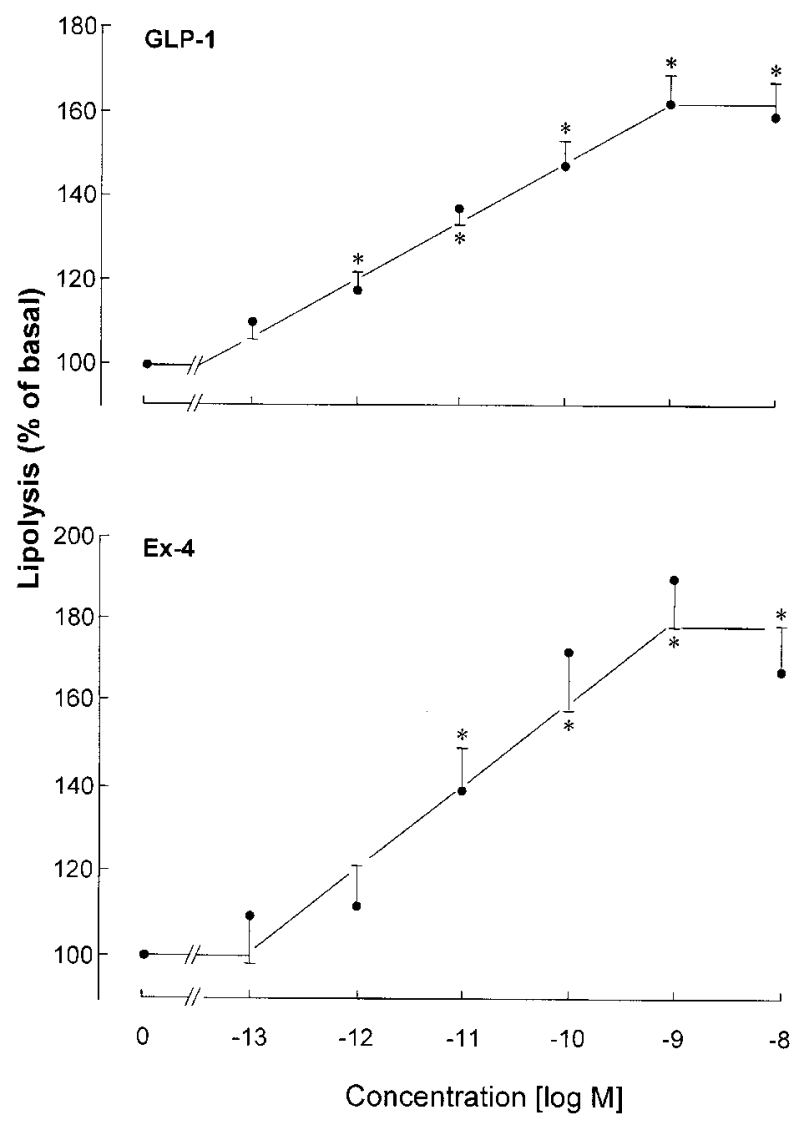

Figure 3 Effects of increasing concentrations of GLP-1 and Ex-4 on lipolysis in normal rat adipocytes. Mean values are expressed as a percentage of the mean basal value found within the same experiment(s), and refer to 10 to 23 separate determinations. ${ }^{*} P<0.05$ compared with the basal value.

relative to the basal value, in an increment of $17 \cdot 0 \pm 3 \cdot 1 \%$ (d.f. $=61 ; P<0 \cdot 001)$.

No effect of Ex-9 upon lipolysis could be detected at any concentration tested. At $10^{-10} \mathrm{M}$, however, Ex-9 $(95 \pm 4 \% ; n=37)$ suppressed the lipolytic action of $10^{-9}$ M GLP-1 (180 $\left.\pm 9 \% ; n=37\right)$ and Ex-4 (159 $\pm 7 \%$; $n=38) \quad$ to $99 \pm 6 \% \quad(n=26) \quad$ and $\quad 96 \pm 9 \% \quad(n=9)$ respectively.

Basal lipolysis was not significantly affected by wortmannin, PD, RAP or RO (Table 2) but was decreased $(P<0.001)$ by $\mathrm{H}-7$. All five potential inhibitors reduced $(P<0 \cdot 05)$ the GLP-1-stimulated lipolysis; however, the values recorded in the presence of both GLP-1 and wortmannin, PD or RAP remained significantly higher $(P<0.005)$ than those obtained in the presence of these agents alone. Such was not the case $(P>0 \cdot 1)$ with $\mathrm{H}-7$ and RO. The response to Ex-4 was abolished by wortmannin and PD, while RAP, H-7 and RO failed to suppress it, the readings recorded in the presence of these three agents alone averaged $85 \pm 3 \% \quad(n=40$; $P<0.001)$ of that found in their absence $(100 \pm 2 \%$; $n=39)$. In the presence of $\mathrm{H}-7$ and glucagon, lipolysis also remained slightly higher $(P<0.01)$ than that in the presence of the inhibitor alone.

In adipocytes of STZ-diabetic rats, basal lipolysis $\left(25 \cdot 1 \pm 3 \cdot 0 \mathrm{nmol}\right.$ glycerol $/ 10^{5}$ cells; $\left.n=10\right)$ was slightly higher $(P<0 \cdot 05)$ than that in normal animals, while the response to GLP-1, Ex-4 and glucagon was essentially comparable, averaging $96 \pm 10 \% \quad(n=10) \quad$ and $163 \pm 11 \% \quad(n=10)$ in the presence of $10^{-12}$ and $10^{-9} \mathrm{M}$ GLP-1, $101 \pm 6 \% \quad(n=10)$ and $144 \pm 10 \%$ $(n=10)$ in the presence of $10^{-12}$ and $10^{-9} \mathrm{M} \mathrm{Ex}-4$, and $170 \pm 13 \%(n=10)$ in the presence of $10^{-9} \mathrm{M}$ glucagon.

\section{Lipogenesis}

In adipocytes from normal rats, the basal rate of lipogenesis averaged $2 \cdot 34 \pm 0 \cdot 15 \mathrm{nmol} / 10^{5}$ cells $(n=214)$. It was enhanced (Table 3$)$ by $10^{-9} \mathrm{M}$ GLP-1, Ex-4 and Ex-9 (all $P<0.001$ ), these effects were not significantly different from one another $(P>0.05)$, but were significantly lower $(P<0.001)$ than that recorded in the presence of $10^{-9} \mathrm{M}$ insulin. As judged from the concentration/response relationships illustrated in Fig. 4, the threshold concentration was lower with Ex-9 than with Ex-4. In the former case, there was only a very slight trend $(r=0 \cdot 1724 ;$ d.f. $=100 ; P<0 \cdot 09)$ for a positive correlation between the rate of lipogenesis and Ex-9

Table 2 Effect of inhibitors of kinase activity on basal and hormone-stimulated lipolysis in adipocytes from normal rats. Results are means \pm S.E.M.

\begin{tabular}{|c|c|c|c|c|}
\hline & Nil & GLP-1 (10-9 M) & Ex-4 $\left(10^{-9} M\right)$ & Glucagon $\left(10^{-9} \mathrm{M}\right)$ \\
\hline Nil & $100 \pm 3(98)$ & $179 \pm 5(80)^{*}$ & $172 \pm 3(41)^{*}$ & $181 \pm 6(22)^{*}$ \\
\hline $\mathrm{W}\left(10^{-4} \mathrm{M}\right)$ & $99 \pm 4(39)$ & $126 \pm 6(29)^{*}$ & $95 \pm 3(10)$ & \\
\hline$P D\left(2.510^{-5} \mathrm{M}\right)$ & $91 \pm 5(43)$ & $110 \pm 4(45)$ & $93 \pm 8(11)$ & \\
\hline $\operatorname{RAP}\left(10^{-7} \mathrm{M}\right)$ & $109 \pm 5(27)$ & $148 \pm 8(30)^{*}$ & $162 \pm 6(9)^{*}$ & \\
\hline $\mathrm{H}-7\left(10^{-4} \mathrm{M}\right)$ & $88 \pm 2(18)^{*}$ & $99 \pm 6(21)$ & $141 \pm 7(22)^{*}$ & $102 \pm 4(22)$ \\
\hline $\mathrm{RO}\left(10^{-7} \mathrm{M}\right)$ & $94 \pm 6(9)$ & $107 \pm 7(9)$ & $123 \pm 5(9)^{*}$ & \\
\hline
\end{tabular}

Numbers in parenthesis indicate number of individual determinations.

W, worthmannin.

${ }^{*} P<0.006$ vs basal value. 
Table 3 Effect of inhibitors of kinase activity on basal and hormone-stimulated lipogenesis in adipocytes from normal rats. Results are means \pm S.E.M.

\begin{tabular}{|c|c|c|c|c|c|}
\hline & Nil & Insulin $\left(10^{-9} \mathrm{M}\right)$ & GLP-1 (10-9 M) & Ex-4 (10-9 M) & Ex-9 $\left(10^{-9} M\right)$ \\
\hline Nil & $100 \pm 4(154)$ & $151 \pm 2(247)^{\star}$ & $130 \pm 3(114)^{\star}$ & $138 \pm 3(114)^{*}$ & $135 \pm 3(142)^{*}$ \\
\hline $\mathrm{W}\left(10^{-6} \mathrm{M}\right)$ & $97 \pm 2(47)$ & $115 \pm 3(20)^{*}$ & $98 \pm 3(22)$ & $102 \pm 6(42)$ & $87 \pm 2(22)^{\star}$ \\
\hline $\mathrm{PD}\left(2.510^{-5} \mathrm{M}\right)$ & $90 \pm 2(47)$ & $126 \pm 5(27)^{*}$ & $89 \pm 3(25)$ & $97 \pm 2(33)$ & $94 \pm 2(35)$ \\
\hline $\operatorname{RAP}\left(10^{-7} \mathrm{M}\right)$ & $106 \pm 3(41)$ & $142 \pm 4(17)^{\star}$ & $117 \pm 7(16)^{*}$ & $101 \pm 3(40)$ & $98 \pm 2(33)$ \\
\hline $\mathrm{H}-7\left(10^{-4} \mathrm{M}\right)$ & $94 \pm 4(27)$ & $144 \pm 11(34)^{*}$ & $115 \pm 7(33)$ & $104 \pm 8(36)$ & $84 \pm 6(22)$ \\
\hline $\mathrm{RO}\left(10^{-7} \mathrm{M}\right)$ & $81 \pm 10(19)$ & $176 \pm 18(21)^{*}$ & $117 \pm 12(21)^{*}$ & $147 \pm 14(20)^{*}$ & $94 \pm 9(20)$ \\
\hline
\end{tabular}

Numbers in parenthesis indicate number of individual determinations.

W, worthmannin.

${ }^{*} P<0.006$ vs basal value.

concentration (logarithmic scale). With both Ex-4 and Ex-9, however, no obvious indication of a dual response was observed. Apparently, a concentration of $10^{-9} \mathrm{M}$ was sufficient for GLP-1, Ex-4 or Ex-9 to cause a maximal lipogenic response; thus, the effects of $10^{-9} \mathrm{M}$ GLP-1 $(131 \pm 6 \%$ of basal value; $n=18), \quad \mathrm{Ex}-4$ $(134 \pm 6 \% ; n=16)$ and $\mathrm{Ex}-9(143 \pm 8 \% ; n=12)$ were not significantly different from one another or from those recorded in the concomitant presence of GLP-1 and either Ex-4 $(137 \pm 7 \% ; n=15)$ or Ex-9 $(139 \pm 11 \%$; $n=12$ ). Nevertheless, the overall mean value of these five sets of measurements $(136 \pm 3 \% ; n=73)$ remained significantly lower $(P<0.02)$ than that recorded with $10^{-9} \mathrm{M}$ insulin $(156 \pm 9 \% ; n=20)$.

The results recorded in the presence of wortmannin, PD, RAP, H-7 or RO alone were not different (Table 3) from the basal value measured within the same experiment(s). The lipogenic response to $10^{-9} \mathrm{M}$ insulin, GLP-1, Ex-4 and Ex-9 was decreased by wortmannin to $85 \cdot 0 \pm 2 \cdot 3 \% \quad(n=106 ; P<0 \cdot 001)$ of the mean corresponding basal value. The rate of lipogenesis in the presence of wortmannin together with GLP-1, Ex-4 or Ex-9 was not different from that in the presence of wortmannin alone, averaging 100.6 $\pm 3 \cdot 2 \% \quad(n=86$; $P>0 \cdot 8$ ) of the latter value; in the concomitant presence of insulin, however, the percentage averaged $117 \cdot 4 \pm 3 \cdot 1 \quad(n=20 ; P<0 \cdot 001)$. Likewise, PD abolished the lipogenic response to GLP-1, Ex-4 and Ex-9 with mean readings averaging $101 \cdot 2 \pm 1 \cdot 5 \% \quad(n=93 ; P>0 \cdot 4)$ of those recorded in the presence of $\mathrm{PD}$ alone. In the presence of insulin and $\mathrm{PD}$, however, the rate of lipogenesis averaged $89 \cdot 4 \pm 3 \cdot 6 \% \quad(n=27 ; \quad P<0 \cdot 05)$ of that found in the presence of insulin alone, and $150 \cdot 0 \pm 6.0 \%(n=27 ; P<0 \cdot 001)$ of that found in the presence of $\mathrm{PD}$ alone.

A comparable situation prevailed in the case of RAP, which decreased $(P<0 \cdot 001)$ the response to the agonists under consideration to $83.9 \pm 1 \cdot 6 \% \quad(n=106)$ of the mean corresponding values found in its absence. In the case of GLP-1, Ex-4 and Ex-9, the residual lipogenesis averaged $97 \cdot 4 \pm 2 \cdot 0 \%(n=89 ; P>0 \cdot 15)$ of that in the presence of RAP alone; in the case of insulin, however, such a percentage amounted to $134 \cdot 6 \pm 3 \cdot 8 \quad(n=17$; $P<0.001)$. However, the inhibitory action of RAP on insulin-stimulated lipogenesis failed to achieve statistical significance. Likewise, $\mathrm{H}-7$ failed to affect the response to insulin, at variance with the response to GLP-1, Ex-4 or Ex-9.

Lastly, RO did not significantly decrease the lipogenic response to insulin or even that to GLP-1, whilst that in the presence of both $\mathrm{RO}$ and $\mathrm{Ex}-4$, but not $\mathrm{RO}$ and Ex-9, remained significantly higher $(P<0 \cdot 001)$ than that recorded in the presence of $\mathrm{RO}$ alone.

For all five inhibitors tested in these experiments, the mean highest lipogenic effect, expressed relative to basal value, was always recorded in cells exposed to insulin $(140 \cdot 4 \pm 4.9 \% ; n=119)$. Lower readings $(P<0 \cdot 001)$ were always obtained with these inhibitors in the presence of either GLP-1 $(106 \cdot 9 \pm 3 \cdot 3 \% ; \quad n=117)$ or $\mathrm{Ex}-4$ $(106 \cdot 5 \pm 3 \cdot 1 \% ; n=171)$. Lastly, the lowest values were, as a rule, recorded in the presence of Ex-9 $(92 \cdot 2 \pm 1.9 \%$; $n=132)$, well below $(P<0.001)$ that found with either GLP-1 or Ex-4.

In adipocytes from STZ-diabetic rats, major differences were found with those of normal animals: the basal value for lipogenesis $\left(5 \cdot 01 \pm 0.58 \mathrm{nmol} / 10^{5}\right.$ cells; $n=33)$ was higher $(P<0.001)$, and the readings recorded in the presence of $10^{-9} \mathrm{M}$ insulin $(172 \pm 7 \% ; n=27)$, relative to basal value, appeared somewhat higher $(P<0 \cdot 01)$ than in normal rats $(151 \pm 2 \% ; n=247)$. Also, in sharp contrast to the situation found in adipocytes from normal rats, no enhancing action upon lipogenesis was detected with either GLP-1, Ex-4 or Ex-9, when tested at either $10^{-12} \mathrm{M}$ or $10^{-9} \mathrm{M}$, the results yielding an overall mean value of $92 \cdot 5 \pm 2 \cdot 0 \%(n=190)$, slightly but significantly $(P<0 \cdot 001)$ lower than unity.

\section{Discussion}

The present findings support the view that in rat adipocytes PI3K, PKB, p70s6k and p44/42 MAPKs are 


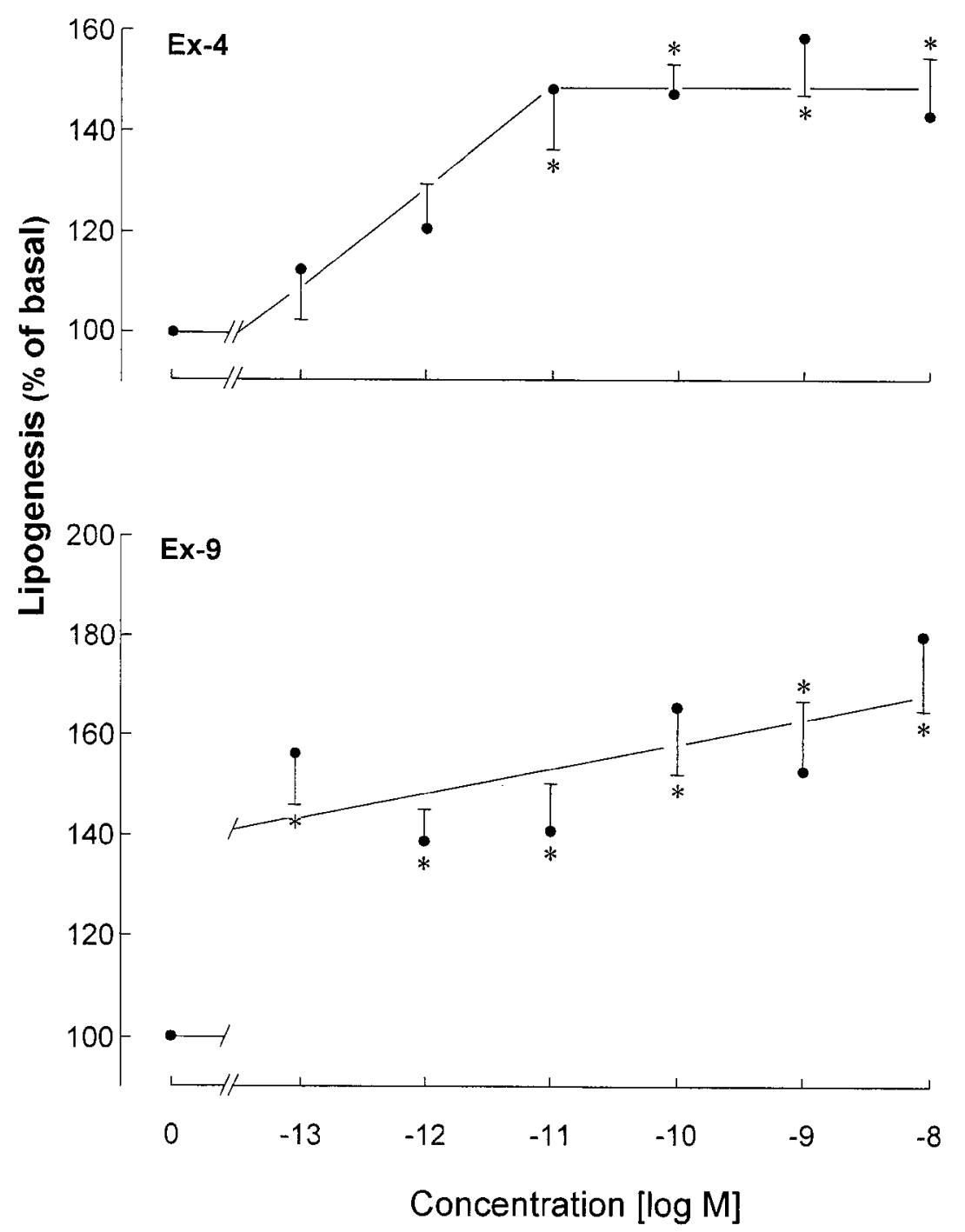

Figure 4 Effects of increasing concentrations of Ex-4 and Ex-9 on lipogenesis in normal rat adipocytes. Mean values are expressed as a percentage of the mean basal value found within the same experiment(s), and refer to 14 to 21 separate determinations. ${ }^{*} P<0.05$ compared with the basal value.

involved in the metabolic response to GLP-1, Ex-4 and Ex-9; indeed, the activity of these kinases was affected by GLP-1 and both exendins. In normal rats, the responses to GLP-1, Ex-4 and Ex-9 were, generally, similar to one another and were higher than (PI3K), comparable to (p70s6K and p44 MAPK) or less than (p42 MAPK) the response evoked by insulin. In this respect, the most dramatic difference consisted in the enhancement of $\mathrm{PKB}$ phosphorylation by insulin, while no increase was detected following GLP-1, Ex-4 or Ex-9; this is in contrast to previous observations in normal rat hepatocytes, in which a clear increment in the enzyme activity evoked by GLP-1, equal in magnitude to that provoked by insulin, was observed (Redondo et al. 2003). The lack of effect of GLP-1, Ex-4 and Ex-9 upon PKB phosphorylation was reversed, however, in the adipocytes of STZ-rats, in which there was also evidence of other anomalies, such as an increased basal PI3K activity, as previously reported in the muscle of type-2 diabetic patients (Meyer et al. 2002, González et al. 2004), and a suppression of the normal positive effect of insulin on p42 and p44 MAPK phosphorylation. The latter result is in contrast to published observations in the skeletal muscle of rats with STZ-induced diabetes, in which insulin-stimulated ERK2 activity and expression was normal (Markuns et al. 1999), and in 
agreement with results from myocytes from type-2 diabetic patients (González et al. 2004), suggesting not only species but also tissue differences in the hormone-signaling pathway.

The comparable effects of GLP-1 and Ex-4 on enzyme phosphorylation in normal rat adipocytes paralleled the effects on 2-deoxy-D-glucose transport. The same was observed for Ex-9, in contrast with its antagonistic character upon the GLP-1 receptor in the beta-cell and other cell systems (Nielsen et al. 2004) and similar to the effect on 3T3 L1 adipocytes (MontroseRafizadeh et al. 1997) and myocytes (Yang et al. 1998). Also it is in accordance with its GLP-1-like action upon glucose transport (González et al. 2005) and metabolism (Luque et al. 2002) in human myocytes. All this indicates tissue and/or species differences in the effects of Ex-9 and its mechanism of action. Moreover, the potential inhibitors of enzyme activity, wortmannin and PD, abolished, as a rule, the effects of insulin, GLP-1, Ex-4 and Ex-9 on glucose transport, as it occurs in human myocytes (González et al. 2005). Such was not the case, however, with RAP, suggesting a more important role for PI3K, MAPKs and possibly PKC than for p70s6K in the control of hexose transport in fat tissue. The postulated involvement of PI3K is further supported by the fact that its increased basal activity in STZ-rats coincided with a higher basal value of 2-deoxy-D-glucose uptake. Likewise, the participation of MAPKs in the regulation of $\mathrm{D}$-glucose transport is consistent with the finding that, in the STZ-rats, the altered effect of insulin on p42 and p44 MAPK phosphorylation occurs together with a preferential impairment of its action on glucose uptake; in fact, insulin, as distinct from GLP-1, Ex-4 and Ex-9, showed both a higher threshold concentration for stimulation of glucose transport and a lower relative magnitude of the metabolic response to higher concentrations of the hormone.

As a general rule, $\mathrm{H}-7$ also abolished the effect of insulin and that of GLP-1, Ex-4 and Ex-9 on D-glucose uptake, as previously observed (except for Ex-9) in human myocytes (González et al. 2005). RO, a staurosporine derivative and potent bisindolylmaleimide inhibitor of mainly $\alpha, \beta_{\mathrm{I}}, \beta_{\mathrm{II}}, \gamma$ and $\varepsilon$ PKC isoforms (Wilkinson et al. 1993), was ineffective on the action of the four hormones/peptides tested, the effect on that of GLP-1 and insulin coinciding with a previous observation in human myocytes (González et al. 2005), and different from that detected on D-glucose metabolism in rat hepatocytes (Redondo et al. 2003). Although nothing definite can be concluded as to whether there are one or several PKC isoforms (Davies et al. 2000) involved in the respective effect of these hormones/peptides, these data do not exclude the possibility of PKC participating in the cellular signaling mechanism of their action.

A different situation prevailed as far as the regulation of lipolysis in normal rat adipocytes is concerned. Indeed,
GLP-1 and Ex-4, but not Ex-9, stimulated glycerol release, thus mimicking the effect of glucagon rather than that of insulin. Ex-9 opposed the lipolytic action of GLP-1 and Ex-4, in accordance with its antagonistic character on the GLP-1 receptor and its effects in other cell systems (Nielsen et al. 2004). Such a lipolytic action was also suppressed, in part at least, by the potential inhibitors of PI3K and MAPKs activity, suggesting that the lipolytic effect of GLP-1 and Ex-4 occurs through activation of either of these two kinases. In adipocytes from STZ-rats, and except for a somewhat higher basal rate of lipolysis (other investigators could not detect any difference in human fat cells (Yu et al. 1997)), the lipolytic response to GLP-1, Ex-4 and glucagon was essentially comparable to that in normal rats.

In adipocytes from normal rats, GLP-1, Ex-4 and also Ex-9 again mimicked, albeit to a somewhat lesser relative extent, the positive effect of insulin on lipogenesis, Ex-9, unexpectedly displaying a very low threshold concentration $\left(\leq 10^{-13} \mathrm{M}\right)$. The sensitivity to the tested inhibitors of kinase activity was lowest in the case of insulin-stimulated lipogenesis and highest in that of Ex-9. Another striking difference between the lipogenic effect of insulin and that of GLP-1 and both exendins consisted in the fact that, in STZ-rats which showed a higher basal value than that in normal animals, no stimulation by GLP-1, Ex-4 and Ex-9 was observed, whilst insulin exerted an increase that was slightly higher than that in normal animals. This more active lipogenic action of insulin in STZ-rats is in accordance with data obtained in type-2 diabetic patients (Lange et al. 1988), but is in contrast with a report in a type-2 diabetic mouse model (Hedeskov et al. 1992). With respect to the present data, there was a close analogy between the opposite effects of GLP-1, Ex-4 and Ex-9 on both PKB phosphorylation and lipogenesis in normal versus diabetic rats, which may suggest a counter regulatory role for this kinase in the hormonal control of lipid generation. This view is further supported by the finding that the higher relative magnitude of lipogenesis induced by insulin in STZ-rats, as compared with normal animals, coincided with a higher relative increment of PKB, as well as PI3K and p70s6K activity.

In summary, the knowledge that certain enzymes are involved in the metabolic responses of the adipocyte to GLP-1 and exendins in STZ-rats, and the fact that the effect of insulin upon some of them is impaired in this diabetic model, adds further information about the mechanism of the overall beneficial action of GLP-1 and Ex-4, whose effects are being currently studied as an alternative therapeutic tool in human diabetes.

\section{Acknowledgements}

We are grateful to C Demesmaeker for secretarial help. 


\section{Funding}

This study was supported by grants from the Ministerio de Educación y Cultura (BFI 2003-07399) and the Institute of Health Carlos III (G03/212 and C03/08), Spain. V S, M V T and N G are Research Fellows from the Fundación Conchita Rábago de Jiménez Díaz. The authors declare that there is no conflict of interest that would prejudice the impartiality of the reported research.

\section{References}

Acitores A, González N, Sancho V, Valverde I \& VillanuevaPeñacarrillo ML 2004 Cell signalling of glucagon-like peptide-1 action in rat skeletal muscle. Fournal of Endocrinology $\mathbf{1 8 0}$ 389-398.

Alcántara AI, Morales M, Delgado E, López-Delgado MI, Clemente F, Luque MA, Malaisse WJ, Valverde I \& Villanueva-Peñacarrillo ML 1997 Exendin-4 agonist and exendin(9-39)amide antagonist of the GLP-1(7-36)amide effects in liver and muscle. Archives of Biochemistry and Biophysics 341 1-7.

Bradford MM 1976 A rapid and sensitive method for the quantitation of microgram quantities of protein utilizing the principle of protein dye binding. Analytical Biochemistry 72 248-254.

Bullock BP, Heller RS \& Habener JF 1996 Tissue distribution of messenger ribonucleic acid encoding the rat glucagon-like peptide-1 receptor. Endocrinology 137 2968-2978.

Cancelas J, Villanueva-Peñacarrillo ML, Valverde I \& Malaisse WJ $2001 a$ Synergistic insulinotropic effects of succinic acid dimethyl ester and exendin-4 in anesthetized rats. International Fournal of Molecular Medicine 8 269-271.

Cancelas J, Villanueva-Peñacarrillo ML, Valverde I \& Malaisse WJ $2001 b$ Suppression by exendin(9-39)amide of glucagon-like peptide 1 insulinotropic action in rats infused with the dimethyl ester of succinic acid. Endocrine 15 283-285.

Creutzfeldt W 2001 The entero-insular axis in type-2 diabetes. Incretins as therapeutic agents. Experimental and Clinical Endocrinology and Diabetes 109 S288-S303.

D’Alessio DA, Prigeon RL \& Ensinck JW 1995 Enteral enhancement of glucose disposition by both insulin-dependent and insulinindependent processes. A physiological role of glucagon-like peptide 1. Diabetes 44 1433-1437.

Dardevet D, Moore MC, Neal D, DiCostanzo CA, Snead W \& Cherrington AD 2004 Insulin independent effects of GLP-1 on canine liver glucose metabolism: duration of infusion and involvement of hepatoportal region. American Fournal of Physiology, Endocrinology and Metabolism 287 E75-E81.

Davies SP, Reddy H \& Caivano M 2000 Specificity and mechanism of action of some commonly used protein kinase inhibitors. Biochemical fournal 351 95-105.

Delgado E, Luque MA, Alcántara A, Trapote MA, Clemente F, Galera C, Valverde I \& Villanueva-Peñacarrillo ML 1995 Glucagon-like peptide-1 binding to rat skeletal muscle. Peptides $\mathbf{1 6}$ 225-229.

González N, Sancho V, Acitores A, Martín-Duce A, Valverde I \& Villanueva-Peñacarrillo ML 2004 Signalling in the GLP-1 and exendins action on glucose transport in myocytes from type-2 diabetic patients. Diabetologia 47 (Suppl 1) A37-A38.

González N, Acitores A, Sancho V, Valverde I \& VillanuevaPeñacarrillo ML 2005 Effect of GLP-1 on glucose transport and its cell signaling in human myocytes. Regulatory Peptides 126 203-211.
Gutniak M, Orskov C, Holst JJ, Ahrén B \& Efendic S 1992 Antidiabetogenic effects of glucagon-like peptide-1(7-36)amide in normal subjects and patients with diabetes mellitus. New England Journal of Medicine 326 1316-1322.

Hedeskov CJ, Capito K, Islin H, Hansen SE \& Thams P 1992 Long-term fat-feeding-induced insulin resistance in normal NMRI mice: postreceptor changes of liver, muscle and adipose tissue metabolism resembling those of type 2 diabetes. Acta Diabetologica 29 14-19.

Laemmli UK 1970 Cleavage of structural proteins during the assembly of the head of bacteriophage T4. Nature 227 680-685.

Lange A, Bak J, Andersen PH, Richelsen B \& Pedersen O 1988 A mixed meal potentiates the insulin sensitivity of glucose transport and metabolism in adipocytes from patients with type 2 diabetes mellitus. Diabetic Medicine 5 761-765.

López-Delgado MI, Morales M, Villanueva-Peñacarrillo ML, Malaisse WJ \& Valverde I 1998 Effects of glucagon-like peptide 1 on the kinetics of glycogen synthase $\alpha$ in hepatocytes from normal and diabetic rats. Endocrinology $1392811-2817$.

Luque MA, González N, Márquez L, Acitores A, Redondo A, Morales M, Valverde I \& Villanueva-Peñacarrillo ML 2002 GLP-1 and glucose metabolism in human myocytes. Fournal of Endocrinology 173 465-473.

Markuns JF, Napoli R, Hirshman MF, Davalli AM, Cheatham B \& Goodyear LJ 1999 Effects of streptozocin-induced diabetes and islet cell transplantation on insulin signaling in rat skeletal muscle. Endocrinology 140 106-111.

Meneilly G, McIntosh CH, Pederson RA, Habener JF, Gingerich R, Egan JM, Finegood DT \& Elahi D 2001 Effects of glucagon-like peptide 1 on non-insulin-mediated glucose uptake in the elderly patient with diabetes. Diabetes Care 24 1951-1956.

Mérida E, Delgado E, Molina LM, Villanueva-Peñacarrillo ML \& Valverde I 1993 Presence of glucagon and glucagon-like peptide-1(7-36)amide receptors in solubilized membranes of human adipose tissue. Founal of Clinical Endocrinology and Metabolism 77 1654-1657.

Meyer MM, Levin K, Grimmsmann T, Beck-Nielsen H \& Klein HH 2002 Insulin signalling in skeletal muscle of subjects with or without type II-diabetes and first degree relatives of patients with the disease. Diabetologia 45 813-822.

Miki H, Namba M, Nishimura T, Mineo I, Matsumara T, Miyagawa J, Nakajima H, Kuwajima M, Hanafusa T \& Matsuzawa Y 1996 Glucagon-like peptide-1(7-36)amide enhances insulin-stimulated glucose uptake and decreases intracellular cAMP content in isolated rat adipocytes. Biochimica et Biophysica Acta 1312 132-136.

Montrose-Rafizadeh C, Yang H, Wang Y, Roth J, Montrose MH \& Adams LG 1997 Novel signal transduction and peptide specificity of glucagon-like peptide receptor in 3T3-L1 adipocytes. Fournal of Cellular Physiology 172 275-283.

Morales M, López-Delgado MI, Alcántara A, Luque MA, Clemente F, Márquez L, Puente J, Viñambres C, Malaisse WJ, Villanueva-Peñacarrillo ML \& Valverde I 1997 Preserved GLP-1 effects upon glycogen synthase $\alpha$ activity and glucose metabolism in isolated hepatocytes and skeletal muscle from diabetic rats. Diabetes 46 1264-1269.

Nielsen LL, Young AA \& Parkes DG 2004 Pharmacology of exenatide (synthetic exedin-4): a potential therapeutic for improved glycemic control of type 2 diabetes. Regulatory Peptides $11777-88$.

Peak M, Rochford JJ, Borthwick AC, Yeaman SJ \& Agius L 1998 Signalling pathways involved in the stimulation of glycogen synthesis by insulin in rat hepatocytes. Diabetologia 41 16-25.

Perea A, Clemente F, Martinell J, Villanueva-Peñacarrillo ML \& Valverde I 1995 Physiological effect of glucagon in human isolated adipocytes. Hormone and Metabolic Research 27 372-375.

Perea A, Viñambres C, Clemente F, Villanueva-Peñacarrillo ML \& Valverde I 1997 GLP-1(7-36)amide effects on glucose transport 
and metabolism in rat adipose tissue. Hormone and Metabolic Research $9417-421$.

Portha B, Picon L \& Rosselin G 1979 Chemical diabetes in the adult rat as the spontaneous evolution of neonatal diabetes. Diabetologia $17371-377$.

Redondo A, Trigo MV, Acitores A, Valverde I \& VillanuevaPeñacarrillo ML 2003 Cell signalling of the GLP-1 action in rat liver. Molecular and Cellular Endocrinology 204 43-50.

Rodbell M 1964 Metabolism of isolated fat cells. I. Effects of hormones on glucose metabolism and lipolysis. Fournal of Biological Chemistry 239 375-380.

Ruiz-Grande C, Alarcón G, Mérida E \& Valverde I 1992 Lipolytic action of glucagon-like peptides in isolated rat adipocytes. Peptides 13 13-16.

Thorens B 1992 Expression cloning of the pancreatic beta cell receptor for the gluco-incretin hormone glucagon-like peptide-1. PNAS 89 8641-8645.

Valverde I, Mérida E, Delgado E, Trapote MA \& VillanuevaPeñacarrillo ML 1993 Presence and characterization of glucagon-like peptide-1(7-36)amide receptors in solubilized membranes of rat adipose tissue. Endocrinology 132 75-79.

Valverde I, Morales M, Clemente F, López-Delgado MI, Delgado E, Perea A \& Villanueva-Peñacarrillo ML 1994 Glucagon-like peptide-1: a potent glycogenic hormone. FEBS Letters 349 313-316.

Vicent D, Villanueva-Peñacarrillo ML, Valverde I \& Malaisse WJ 1994 Impaired in vivo insulin secretion in response to non-glucidic secretagogues in adult rats after neonatal streptozotocin. Acta Diabetologica 31 133-137.

Villanueva-Peñacarrillo ML, Alcántara A, Clemente F, Delgado E \& Valverde I 1994 Potent glycogenic effect of GLP-1(7-36)amide in rat skeletal muscle. Diabetologia 37 1163-1166.
Villanueva-Peñacarrillo ML, Delgado E, Trapote MA, Alcántara AI, Clemente F, Luque MA, Perea A \& Valverde I 1995

Glucagon-like peptide-1 binding to rat hepatic membranes. Fournal of Endocrinology 146 183-189.

Villanueva-Peñacarrillo ML, Márquez L, González N, Díaz-Miguel M \& Valverde I 2001 a Effect of GLP-1 on lipid metabolism in human adipocytes. Hormone and Metabolic Research 33 73-77.

Villanueva-Peñacarrillo ML, Puente J, Redondo A, Clemente F \& Valverde I $2001 b$ Effect of GLP-1 treatment on GLUT2 and GLUT4 expression in NIDDM and IDDM rats. Endocrine 15 241-248.

Wang Y, Kole HK, Montrose-Rafizadeh G, Perfetti R, Bernier M \& Egan JM 1997 Regulation of glucose transporters and hexose uptake in 3T3-L1 adipocytes: glucagon-like peptide-1 and insulin interactions. Fournal of Molecular Endocrinology 19 241-248.

Wieland O 1963 Glycerol. In Methods in Enzymatic Analysis, pp 211-214. Ed HU Bergmeyer. New York: Academic Press.

Wilkinson SE, Parker PJ \& Nixon JS 1993 Isoenzyme specifity of bisindolylmaleimides, selective inhibitors of protein kinase C. Biochemical fournal 294 335-337.

Yang H, Egan JM, Wang Y, Moyes D, Roth J, Montrose MH \& Montrose-Rafizadeh C 1998 GLP-1 action in L6 myotubes is via a receptor different from the pancreatic GLP-1 receptor. American Journal of Physiology 275 C675-C683.

Yu ZW, Jansson PA, Posner BI, Smith U \& Eriksson JW 1997 Peroxovanadate and insulin action in adipocytes from NIDDM patiens. Evidence against a primary defect in tyrosine phosphorylation. Diabetologia 40 1197-1203.

Received 28 April 2005

Accepted 4 May 2005 